УДК 94 (477.74): 908 (043.5)

DOI 10.12958/2227-2844-2021-4(342)-176-187

\title{
Щербина Надія Федорівна,
}

кандидат історичних наук, доцент кафедри філософії, історії та політології

Одеського національного економічного університету,

м. Одеса, Україна.

NadinF@ukr.net

https://orcid.org/0000-0002-9399-1418

\section{БІБЛІОТЕКИ ТА ЇХ ДІЯЛЬНІСТЬ У КОНТЕКСТІ ІСТОРИКО-КРАЕЗНАВЧОГО РОЗВИТКУ В РЕГІОНІ}

Вивчення історії бібліотечної справи в України загалом та історії окремих книгозбірень зокрема, стало в сучасних умовах одним із напрямів науково-дослідної і краєзнавчої роботи бібліотек. Це цілком закономірне явище: великі зміни, які відбуваються в житті нашої країни, викликають у суспільстві прагнення до вивчення минулого свого народу, своїх коренів, до відродження національної культури. У такій ситуації люди здебільшого сьогодні звертаються до інтернету, однак не знайшовши повної інформації повертаються до книг, до бібліотек.

Бібліотечне краєзнавство здатне заповнити в людях духовний вакуум, оскільки духовність зростає, розвивається разом 3 любов'ю до рідного краю. Від минулих часів у сфері бібліотечного краєзнавства залишилася невідрадна спадщина. Важлива роль у збереженні національної пам'яті належить бібліотечному краєзнавству, мета якого зібрати, зберегти та надати читачам документальні джерела та інформацію 3 історії, культури і сучасної життєдіяльності краю Мета даної статті показати участь бібліотек протягом 40-х - 80-х рр. ХХ ст. у відновленні та розвитку історичного краєзнавства в регіоні, на прикладі Одещини.

Історико-краєзнавча діяльність бібліотек має давні традиції. Бібліотечне краєзнавство було започатковано ще першими публічними книгозбірнями, видатними вченими і громадськими діячами. За довгі роки у бібліотеках сформувалися провідні напрямки краєзнавчої роботи. Фальсифікацій, перекручень i замовчувань у не надто численних історико-бібліотечних дослідженнях 50-х - 80-х pp. ХХ ст. було більш ніж достатньо i це трагедія тогочасних дослідників, які не мали можливості подолати штучні ідеологічні перепони.

Краєзнавчий доробок бібліотечних установ України, на рівні відомчих інформаційних матеріалів та окремих праць у часописах i збірниках матеріалів наукових конференцій, не дає чіткого уявлення про 
еволюцію змісту, форм та методів краєзнавчої роботи бібліотек у складний і суперечливий час 40-х - 80-х pp. XX ст. Розгортанню краєзнавчої бібліографічної роботи у повоєнні роки присвячена праця I. Корнейчука, в якій на конкретних прикладах висвітлена діяльність одеських бібліотек (Корнейчук, 1968). Історико-краєзнавча діяльність бібліотечних установ Одеської області переважно висвітлена у часописах та збірниках матеріалів наукових регіональних та всеукраїнських конференцій. Досвід бібліотек Одещини у краєзнавчій тематиці висвітлювали у своїх працях Г. Каширін (1960), Т. Полянко (1965; 1966), О. Панова (2003), Л. Смичок, Л. Забенкіна (1989) та ін. Дослідники, поряд з позитивними моментами у сфері краєзнавчої роботи бібліотек, наголошували й на недоліках, які негативно позначалися як на діяльності бібліотек, так і на розвитку краєзнавчого руху на Одещині взагалі.

Теоретичні і методичні основи краєзнавчих фондів у бібліотеках набули певного оформлення у другій половині 50-х - на початку 60-х рр. ХХ ст. у зв'язку з розробкою і затвердженням у 1959 р. „Положення про краєзнавчу роботу обласних крайових, республіканських бібліотек" (Положение, 1982). У 1978 р. було затверджено і „Положення про краєзнавчу роботу бібліотек системи Міністерства культури УРСР" (Положення, 1978). Вагому методичну допомогу у сфері бібліотечного краєзнавства надавала Державна наукова історична бібліотека України, яка видавала методичні рекомендації для обласних бібліотек (Методические, 1983).

Бібліотечне краєзнавство на Одещині, як i в країні, було започатковане ще у XIX ст. На цей час припадає виникнення перших бібліотек у місті, таких як - наукова бібліотека Одеського національного університету ім. I. Мечникова, Одеська державна наукова бібліотека ім. М. Горького, Одеська державна обласна наукова бібліотека ім. В. Леніна.

Слід зазначити, що в XIX ст. краєзнавча діяльність бібліотек була епізодичною, а бібліографічна робота проводилась фактично поза бібліотечними закладами. Натомість в 20-ті роки XX ст. в Одесі розгортається широка краєзнавча робота, координаційним центром якої виступала Одеська комісія краєзнавства. На превеликий жаль, в архівах не зберіглося документів про ту краєзнавчу роботу, яку проводили місцеві бібліотеки у 20-ті pp. Але побічні матеріали вказують на те, що ця робота проводилася активно. Особливо треба підкреслити, що усі бібліотеки міста працювали разом над невирішеними завданнями. Це, наприклад, проявилося у розробці такої фундаментальної бібліографічної праці з краєзнавства як „Одеська періодична преса років революції та громадянської війни. 1917-1921 рр.” за редакцією С. Рубинштейна (1929). В створенні фундаментального дослідження, яке не втратило свого наукового значення і сьогодні, активну участь брали працівники наукової бібліотеки Одеського державного університету 
iм. I. Мечникова, державної наукової бібліотеки ім. М. Горького, Української державної бібліотеки ім. Т. Шевченка та інші установи і заклади міста. У роботі описані, за рідким винятком, всі періодичні видання, які виходили в Одесі у 1917-1921 рр. російською, українською, англійською, болгарською, грецькою, польською, єврейською, литовською, німецькою, румунською, французькою, сербо-хорватською мовами. Всього було опрацьовано 267 найменувань газет та 189 журналів (Павлюк, 1958). В праці надається покажчик видавців і видавництв, редакторів, типографій, наявність газет та журналів у бібліотеках. Саме 3 цього періоду наукові бібліотеки міста починають ставати центрами краєзнавчої роботи в Одесі.

Великих збитків краєзнавству завдано у 30-ті pp. XX століття: було репресовано або усунено від активної діяльності багато краєзнавців, невиправдано вилучено з обігу ряд цінних краєзнавчих видань. Під час Другої світової війни і фашистської окупації міста фонди бібліотек дуже постраждали: частково знищені, були пограбовані, вивезені. Тільки в Одеській обласній науковій бібліотеці ім. В. Леніна було знищено понад 5 тисяч книг, вивезена і спалена цінна частина колекції "Hebraica" книги на давньоєврейській мові, караїмська література та багато інших видань (Полянко, 2003).

Після закінчення війни почався новий етап у розвитку бібліотечного краєзнавства. Бібліотеки області, як і всієї республіки, почали відновлювати роботу, зіткнувшись з багатьма проблемами: у деяких бібліотеках ще не були відновлені книжкові фонди, виникали труднощі з приміщеннями, був потрібен час для створення довідковобібліографічного апарату.

В країні у зв'язку 3 розвитком народного господарства й культури, зростало значення й краєзнавчої бібліографії. У 1948 р. у Києві відбулася республіканська нарада бібліотечних працівників, яка запропонувала бібліотекам України активізувати свою діяльність в області краєзнавства (Про стан, 1948). У перше повоєнне десятиріччя основну роль у розвитку краєзнавчої бібліографії на Україні відігравали наукові i академічні бібліотеки. Однією 3 першою до краєзнавчої бібліографічної роботи звернулася Одеська державна наукова бібліотека ім. М. Горького, яка була заснована ще у 1829 р. як Одеська міська публічна бібліотека i мала давні краєзнавчі традиції. Основу іiі краєзнавчого фонду складали пожертвування книг з історії, археології та географії Північного Причорномор'я, які зробили ініціатори створення бібліотеки - О. Льовшин, I. Стемковський та інші. Краєзнавчого напрямку в комплектуванні фонду бібліотека набула завдяки діяльності історика М. Мурзакевича. Книжкові зібрання зростали, головним чином, за рахунок дарунків меценатів. Особливу цінність становили колекції графа М. Воронцова (600 видань), графа М. Толстого (понад 40000 видань), міського голови, мецената Г. Маразлі (10000 видань) та інші 
(Ботушанська, 2004, с. 3). У 1875 р. бібліотекарем М. Дерібасом було покладено початок створення відділу „Новоросика”. У історикокраєзнавчій діяльності бібліотеки значним досягненням було створення „Музею одеської старовини”, заснування якого пов'язано 3 іменем М. Толстого - попечителя бібліотеки протягом двадцяти років. На основі цього музею було створено ще й музей книги бібліотеки, а згодом відділ рідкісних видань та рукописів. Саме завдяки діяльності попечителів бібліотеки, таких як О. Стуарт, К. Сікард, М. Попруженко, М. Толстой та інших бібліотека перетворилася на провідний культурний i краєзнавчий центр Одеси: було випущено друковані каталоги, організовано палітурну майстерню, налагоджено найтісніші контакти 3 багатьма бібліотеками світу.

У повоєнні роки Одеській державній науковій бібліотеці ім. М. Горького вдалося за короткий термін часу зібрати і відновити свої книжкові фонди, а також упорядкувати каталоги. Вона намагалася налагодити складання і видання бібліографічних посібників.

Працівники Одеської наукової бібліотеки ім. М. Горького плідно працювали над доповненням спеціалізованої картотеки „Одесика”, яка була створена ще на початку 20-х рр. XX ст. - це зведений каталог краєзнавчої літератури, який включав монографії, статті, публікації в періодичній пресі, рецензії та інші матеріали, які висвітлювали різні аспекти історії Одещини. У різні періоди свого існування картотека мала неоднаковий характер поповнення. Спочатку в картотеці приділялось більше уваги діяльності численних доброчинних товариств та закладів, які виникали в Одесі, а також діяльності меценатів, пізніше в картотеці переважали матеріали, присвячені діяльності етнічних груп у розвитку культури нашого краю, а у повоєнні роки основний матеріал носив ідеологічне спрямування, наприклад широко висвітлювалась діяльність Одеської партійної організації, звичайно поряд з цим збирався і матеріал 3 історії та культури Одещини. 3 часом „Одесика” мала найбільш повний і найбільш доступний довідковий апарат про наш край.

За роки існування Одеської наукової бібліотеки ім. М. Горького простежується оптимізація окремих аспектів бібліографічної роботи 3 питань краєзнавства, яка здійснювалася шляхом формування та організації довідково-бібліографічного апарату, бібліотечного обслуговування, складання краєзнавчих посібників тощо.

3 другої половини XX ст. в Україні помітно збільшується число бібліотек, що активно займалися краєзнавчою бібліографією. Плідно діяли в Одеській області наукові й університетські бібліотеки, робота яких засвідчує, що краєзнавство стало однією 3 найважливіших напрямків їх діяльності. Розпочалася краєзнавча робота у відомчих бібліотеках, розширювалася мережа масових бібліотек області, яка сприяла розвитку різноманітних форм краєзнавчої діяльності. 
Велику увагу регіональним краєзнавчим дослідженням приділяла Наукова бібліотека Одеського державного університету ім. I. Мечникова (нині Одеський національний університет ім. I. Мечникова), яка була створена у 1817 р. як бібліотека Одеського (Ришельєвського) ліцею - першого на півдні Російської імперії вищого навчального закладу. Після перетворення ліцею у 1865 p. на Новоросійський університет бібліотека, яка на той час уже мала значний фонд наукової і навчальної літератури, увійшла до складу університету як фундаментальна бібліотека. Здебільшого бібліотека збагачувалась колекціями книг, що їх дарували приватні особи та наукові, культурнопросвітницькі, доброчинні заклади. Так, наприклад, в різні часи до бібліотеки надійшли найцінніші фонди В. Григоровича, М. Воронцова, О. Строганова, М. Шильдера, Б. Ляпунова, А. Готалов-Готліба, Ф. Петруня та ін. (Бондаренко, 1965, с. 78).

Значне місце у діяльності наукової бібліотеки університету у другій половині XX ст. займала науково-бібліографічна і краєзнавча робота, спрямована на розкриття потенціалу книжкових фондів, складання науково-інформаційної бібліографії для сприяння роботи дослідників, бібліографічних списків, покажчиків та картотек. Працівниками бібліотеки була створена розгалужена система каталогів, які відображали i розкривали фонди в усій їх повноті. Науковобібліографічна і краєзнавча робота бібліотеки була направлена на більш повне задоволення зростаючих потреб читачів. Для цього застосовувалися різноманітні методи та форми роботи: виставки, видання бібліографічних покажчиків, бібліографічні огляди, індивідуальні інформації 3 історії краю, сучасного його розвитку. Внаслідок діяльності наукової бібліотеки університету вийшли друком краєзнавчі видання зокрема такі, як:

1) Матеріали до біобібліографічного словника професорськовикладацького складу Одеського державного університету ім. І. Мечникова, в якому розглядався внесок близько 800 вчених університету у вітчизняну та світову науку, які працювали в університеті з 1865 р. по 1957 р. Картотека праць вчених біографічного і наукового характеру нараховувала понад 16 тисяч карток;

2) Систематичний покажчик до „Записок Новоросійського університету" за 1867-1919 рр., який включав понад 1000 праць з усіх профільних наук, які викладалися в університеті;

3) Систематичний покажчик до „Записок” наукових товариств при Новоросійському університеті” та інші покажчики, присвячені природним ресурсам, розвитку сільського господарства області та ін. (Павлюк, 1958). Ці систематичні покажчики і сьогодні $\epsilon$ цінними бібліографічними посібниками для дослідників тому, що університет, та його наукові товариства виконували значну роль не тільки у розвиток 
вітчизняної та світової науки і культури, а також у розвиток одеського регіону.

Становленню бібліотечного краєзнавства у 50-80-ті pp. XX ст. в Україні значною мірою сприяла робота обласних бібліотек як методичних центрів культурно-масової роботи. В Одеській області таким центром стала обласна наукова бібліотека ім. В. Леніна (нині Одеська обласна універсальна наукова бібліотека ім. М. Грушевського), яка була заснована у 1875 р. як громадська бібліотека при Одеському товаристві взаємної допомоги прикажчиків-євреїв. Обласні бібліотеки України через величезний збиток, завданий у роки Другої світової війни їхнім книжковим фондам, довго не в змозі були налагодити роботу щодо складання й видання краєзнавчих бібліографічних посібників. Після звільнення у квітні 1944 р. Одеси від німецько-фашистських окупантів Одеська обласна наукова бібліотека ім. В. Леніна відновила свою роботу у травні, і вже у наступному році налічувала 175 тисяч книг та 10 тисяч читачів (Скарбниця культури, 1955, с. 26). Проте, протягом першого післявоєнного десятиліття зусилля бібліотеки у сфері краєзнавчої бібліографії були спрямовані в основному на підготовку краєзнавчих картотек і каталогів.

Характерною рисою розвитку рекомендаційної краєзнавчої бібліографії у досліджуваний період було видання бібліографічних посібників „малих форм”. Поряд із покажчиками й бібліографічними пам'ятками видавалися численні короткі списки літератури, випускалися серії листівок, покажчики про книги, бібліографічні огляди й плакати, розроблялися плани для читання тощо. Незважаючи на труднощі, використання у краєзнавчій роботі найрізноманітніших форм рекомендаційної бібліографії свідчило про ефективність пропаганди краєзнавчої літератури, здійснюваної бібліотеками області. Але перевага „малих форм”, відсутність змістовних покажчиків основної літератури про край свідчило й про інше - про недостатній рівень розвитку рекомендаційної краєзнавчої бібліографії в області, як і в країні взагалі.

Активізації краєзнавчої роботи сприяло проведення в Україні у 80-ті рр. централізації бібліотечної системи, у результаті якої змінилися завдання методичних центрів, бібліотекам на місцях надавалося більше самостійності у роботі.

Підвищенню рівня краєзнавчої роботи сприяла також творча співпраця колективів бібліотек з науковими організаціями і установами області, які займалися краєзнавчою діяльністю. Особливо плідною була взаємодія бібліотек та середніх шкіл у створенні та діяльності численних краєзнавчих музеїв та краєзнавчих кімнат на громадських засадах, краєзнавчих гуртків при середніх школах, а деякі музеї навіть були організовані на базі бібліотек. В результаті такого співробітництва набагато розширювалися можливості краєзнавчої роботи бібліотек, підвищувалася іiі ефективність, поглиблювався зміст. 
Завдання районних бібліотек полягали у наданні допомоги бібліотекарям села оволодіти необхідними знаннями, навичками в роботі 3 краєзнавчою літературою. Форми методичної допомоги були різними це i методична доповідь, консультація, i обмін досвідом 3 питань краєзнавчої роботи на постійно діючих семінарах, i поради у комплектуванні фондів бібліотек краєзнавчою літературою, у виявленні і доборі краєзнавчих матеріалів тощо. Під час відвідування сільських бібліотек працівники районних бібліотек надавали практичну допомогу щодо організації книжкових виставок, виготовлення тематичних папок газетних вирізок, оформлення бібліотечних плакатів та інших питань. Так, Біляївська районна бібліотека шляхом складання методичних розробок, сприяла більш змістовному і якісному проведенні сільськими бібліотеками краєзнавчих заходів: літературних вечорів, обговорень книг про історію свого села, зустрічей із відомими земляками. Деякі районі бібліотеки, проводячи читацькі конференції, літературні вечори на краєзнавчі теми, запрошували на них сільських бібліотекарів, надаючи цим заходам показового характеру. Застосування таких форм навчання, наприклад Новосельницькою районною бібліотекою, допомагало сільським бібліотекарям краще організовувати роботу з пропаганди краєзнавчої роботи (Каширін, 1960, с. 35).

У діяльності бібліотек області у 70-ті - 80-ті рр. простежуються деякі недоліки. Книжкові фонди далеко не в повній мірі задовольняли вимоги, які ставили перед бібліотеками в галузі краєзнавства. Особливо обмеженими були фонди районних і сільських бібліотек, зокрема краєзнавчої тематики. Бібліографічні посібники не відбивали повністю і не розкривали всіх сторін історичного розвитку і багатогранного життя краю. Як правило, вони носили тематичний характер і багато питань не знаходили свого висвітлення. При складанні картотек бібліотечні працівники не завжди вміли відібрати потрібний матеріал, який мав цінність для наукових досліджень.

Отже, в організації краєзнавчої діяльності на Одещині значна роль у досліджуваний період належала науковим та масовим бібліотекам. Краєзнавча робота бібліотек включала виявлення, збирання i систематизацію краєзнавчої літератури (внаслідок чого у бібліотеках створювалися цінні краєзнавчі фонди); довідково-бібліографічне обслуговування різних установ і окремих читачів (створення зведених алфавітних каталогів, рекомендованих картотек, альбомів, підборок газетних і журнальних статей, бюлетнів нових надходжень, а також організація виставок, бібліографічних оглядів, тематичних заходів краєзнавчого характеру); науково-методична діяльність, зокрема допомога сільським бібліотекам та бібліотекам підприємств, створення методичних посібників, проведення консультацій, семінарів, нарад i конференцій, які сприяли обміну досвідом краєзнавчої роботи в регіоні тощо. У справі розвитку бібліотечного краєзнавства важливу роль 
відігравали бібліографи-краєзнавці одеських наукових бібліотек, зокрема такі, як О. Вовчок, М. Десенко, Г. Каширін, Л. Смичок, О. Ноткіна, Н. Павлюк, С. Фельдман, О. Панова, Т. Полянко та багато інших.

Слід зазначити, що у досліджуваний період деякі недоліки в діяльності бібліотек значно знижували рівень розвитку бібліотечного краєзнавства на Одещині. Бібліотеки не в повній мірі використовували свої можливості - розвивалася в основному краєзнавча бібліографія, але збільшення випуску різних покажчиків літератури не позначилося на підвищенні якості довідково-бібліографічного та інформаційного обслуговування. Бібліотеки не координували свою діяльність щодо комплектування краєзнавчих фондів в регіоні, недостатньо, особливо в спеціальних бібліотеках, вивчався їх склад і ефективність використання. Деякі районні бібліотеки були пасивними у залученні населення до читання краєзнавчої літератури, формуванні своєї читацької аудиторії. Вони не враховували всі історичні, демографічні, культурні особливості краю, що знижувало ефективність їх роботи, призводило до вихолощення не тільки національної, але і регіональної специфіки. Великий об'єм бібліографічних краєзнавчих ресурсів, 3 одного боку, i невисока їх ефективність, неповнота і розрізненість краєзнавчих фондів, слабка їх пропаганда, методичний різнобій - 3 іншого, призводили до негативних результатів. Потреби громадськості в краєзнавчих документах недостатньо задовольнялися бібліотечними закладами, особливо сільськими. До кола недоліків у роботі бібліотек можна віднести і залишковий принцип фінансування культури, і слабку матеріальнотехнічну базу бібліотек, і тривалі перерви у надходженні обов'язкового безкоштовного місцевого екземпляру друкованих творів, і відсутність спеціалізованих краєзнавчих відділів, а також добре підготовлених для них кадрів. На розвитку бібліотечного краєзнавства в регіоні негативно позначилися ті загальні тенденції суспільного життя, що випливали 3 самого характеру існуючого тоді тоталітарного режиму, а саме надмірна заполітизованість, жорстка ідеологізація всієї гуманітарно-культурної, духовної сфери суспільного буття. Втім, краєзнавча діяльність бібліотек області потребує подальшого поглибленого вивчення, адже на той час вони, виступаючи регіональними інформаційними центрами, займалися пошуком, збереженням і наданням у суспільне користування краєзнавчої літератури.

\section{Список використаної літератури}

1. Корнейчук И. Развитие краеведческой библиографии в советское время (1941-1967 гг.). Харьков : Б. и., 1968. 45 с. 2. Каширін Г. Краєзнавча робота масової бібліотеки. К. : Держ. вид-во політ. л-ри УРСР, 1960. 39 с. 3. Панова А. Край мой - гордость моя. Библиотекарь. 1966. № 1. С. 57-59. 4. Панова О. Краєзнавчу літературу - трудящим! Краєзнавство в бібліотеці. 3 досвіду роботи. К. : Політвидав України, 1965. С. 7-12. 5. Полянко Т. Деятельность 
библиотек Одесской области в изучении истории региона и создании краеведческих информационных ресурсов. Наукова бібліотека в сучасному суспільстві: Історія, проблеми, перспективи: До 185-річчя Наукової бібліотеки Одеського начіонального ун-ту ім. I. Мечникова: зб. cm. / Відп. ред. В. Сминтина. Одеса: Астропринт, 2003. С. 26-31. 6. Смычок Л., Забенкина Л. Историко-краеведческая деятельность Одесской государственной научной библиотеки им. М. Горького. Тезисы I областной историко-краеведческой научно-практической конференции, посвященной 200-летию г. Одессы „Воспитание историей”. Одесса, 1989. С. 121-122. 7. Положение о краеведческой работе областных, краевых, республиканских (АССР) библиотек. Руководящие материаль по библиотечному делу: справочник. М. : Книга, 1982. С. 192-196. 8. Положення про краєзнавчу роботу бібліотек системи Міністерства культури УРСР. К., 1978. 9 с. 9. Методические рекомендации по формированию краеведческих фондов библиотек УССР / сост.: А. Комская, Л. Александрова. К. : Б. и., 1983. 12 с. 10. Праці Одеської Центральної наукової бібліотеки. Одеса : Б. в., 1929. XLVIII. 175 с. 11. Павлюк Н. Краеведение в библиотеках. Сокровищница культуры: сб. сm. / ред. В. А. Загоруйко. Одесса, 1958. Вип. 2. С. 104-120. 12. Про стан і завдання бібліотечної роботи в УРСР. Резолюція республіканської наради бібліотечних працівників України. Культурно-освітня робота. 1948. № 12. С. 14-24. 13. Ботушанська О. Скарбниці культури України - 175. Скарбниия культури: зб. сm. / ред. І. Шелестович. Одеса, 2004. Вип. 3. С. 3-21. 14. Бондаренко П. Розвиток наукової бібліотеки Одеського державного університету. Тези доповідей та повідомлень ювілейної наукової сесії, присвячена 100-річчю Одеському державному ун-ту. Одеса, 1965. С. 77-79. 15. Скарбинця культури / ред. В. Загоруйко. Одеса : ОДНБ ім. М. Горького. 1955. 128 с.

\section{References}

1. Kornejchuk, I. (1968). Razvitie kraevedcheskoj bibliografii v sovetskoe vremya (1941-1967 gg.) [Development of local lore bibliography in Soviet times (1941-1967)]. Har'kov: B. i. [in Russian]. 2. Kashyrin, H. (1960). Krayeznavcha robota masovoyi biblioteky [Local lore work of the public library]. Kyiv: Derzh. vyd-vo polit. l-ry URSR [in Ukrainian]. 3. Panova, A. (1966). Kraj moj - gordost' moya [My land is my pride]. Bibliotekar', 1, 57-59 [in Russian]. 4. Panova, O. (1965). Krayeznavchu literaturu - trudyashchym! [Local lore literature - for workers!]. Krayeznavstvo $v$ bibliotetsi. $Z$ dosvidu roboty - Local lore in the library. From work experience. (pp. 7-12). Kyiv: Politvydav Ukrainy [in Ukrainian]. 5. Polyanko, T. (2003). Deyatel'nost' bibliotek Odesskoj oblasti v izuchenii istorii regiona i sozdanii kraevedcheskih informacionnyh resursov [The activity of libraries in the Odessa region in the study of the history of the region and the creation of local lore information resources]. Naukova 
biblioteka v suchasnomu suspil'stvi: Istoriya, problemy, perspektyvy: Do 185 richchya Naukovoyi biblioteky Odes'koho natsional'noho un-tu im. I. Mechnykova [Scientific library in modern society: History, problems, prospects: To the 185th anniversary of the Scientific Library of Odessa National University after I. Mechnikov]. (pp. 26-31). Odesa: Astroprynt [in Russian]. 6. Smychok, L., \& Zabenkina, L. (1989). Istoriko-kraevedcheskaya deyatel'nost' Odesskoj gosudarstvennoj nauchnoj biblioteki im. M. Gor'kogo [Istorical and local lore activities of the Odessa State Scientific Library after M. Gorky]. Tezisy I oblastnoj istoriko-kraevedcheskoj nauchno-prakticheskoj konferencii, posvyashchennoj 200-letiyu g. Odessy „Vospitanie istoriej” Abstracts of the first regional historical and local lore scientific-practical conference dedicated to the 200th anniversary of Odessa "Education by history”. (pp. 121-122). Odessa [in Russian]. 7. Polozhenie o kraevedcheskoj rabote oblastnyh, kraevyh, respublikanskih (ASSR) bibliotek [Regulations on local lore work of regional, regional, republican (ASSR) libraries]. (1982). Rukovodyashchie materialy po bibliotechnomu delu: spravochnik - Guiding materials on library business: reference book. (pp. 192-196). M.: Kniga [in Russian]. 8. Polozhennya pro krayeznavchu robotu bibliotek systemy Ministerstva kul'tury URSR [Regulations on local lore work of libraries of the system of the Ministry of Culture of the USSR]. (1978). Kyiv [in Ukrainian]. 9. Komskaya, A., \& Aleksandrova, L. (Comp.). (1983). Metodicheskie rekomendacii po formirovaniyu kraevedcheskih fondov bibliotek USSR [Methodical recommendations for the formation of local lore funds of libraries of the USSR]. K.: B. i. [in Russian]. 10. Pratsi Odeskoi Tsentralnoi naukovoi biblioteky [Proceedings of the Odessa Central Scientific Library]. (1929). XLVIII. Odesa: B. v. [in Ukrainian]. 11. Pavlyuk, N. (1958). Kraevedenie v bibliotekah [Local lore in libraries]. Sokrovishchnica kul'tury - Treasury of Culture. (Issue 2), (pp. 104-120). Odessa [in Russian]. 12. Pro stan i zavdannia bibliotechnoi roboty v URSR. Rezoliutsiia respublikanskoi narady bibliotechnykh pratsivnykiv Ukrainy [On the state and objectives of library work in the USSR. Resolution of the republican meeting of librarians of Ukraine]. (1948). Kulturno-osvitnia robota - Cultural and educational work, 12, 14-24 [in Ukrainian]. 13. Botushanska, O. (2004). Skarbnytsi kultury Ukrainy - 175 [Treasury of culture of Ukraine - 175]. Skarbnytsia kultury Treasury of culture. (Issue 3), (pp. 3-21). Odesa [in Ukrainian]. 14. Bondarenko, P. (1965). Rozvytok naukovoi biblioteky Odeskoho derzhavnoho universytetu [Development of the scientific library of Odessa State University]. Tezy dopovidei ta povidomlen yuvileinoi naukovoi sesii, prysviachena 100-richchiu Odeskomu derzhavnomu un-tu - Abstracts of reports and announcements of the anniversary scientific session dedicated to the 100th anniversary of Odessa State University. (pp. 77-79). Odesa [in Ukrainian]. 15. Zahoruiko, V. (Ed.). (1955). Skarbnytsia kultury [Treasury of Culture]. Odesa : ODNB im. M. Horkoho [in Ukrainian]. 


\section{Щербина Н. Ф. Бібліотеки та їх діяльність у контексті історико-краєзнавчого розвитку в регіоні \\ У статті розкрита історико-краєзнавча діяльність бібліотек} Одещини у другій половині 40-х - 80-х рр. XX ст. Аналіз цієї діяльності свідчить про те, що незважаючи на великі труднощі (залишковий принцип фінансування культури, і слабку матеріально-технічну базу бібліотек) вони стали справжніми центрами краєзнавчої роботи у регіоні. Бібліотеки нагромадили за цей період значну бібліографічну базу 3 питань краєзнавства, набули великого досвіду в роботі 3 історикокраєзнавчих досліджень. Практично у кожній бібліотеці було зібрано краєзнавчий фонд, створено каталоги й картотеки, що включали численні матеріали 3 різноманітною краєзнавчою тематикою. Втім, краєзнавча діяльність бібліотек області потребує подальшого поглибленого вивчення, адже на той час вони, виступаючи регіональними інформаційними центрами, займалися пошуком, збереженням і наданням у суспільне користування краєзнавчої літератури. На розвиток бібліотечного краєзнавства в регіоні негативно позначилися ті загальні тенденції суспільного життя, що випливали 3 самого характеру існуючого тоді тоталітарного режиму.

Ключові слова: історичне краєзнавство, бібліотека, культура, краєзнавча література, бібліографія.

Щербина Н. Ф. Библиотеки и их деятельность в контексте историко-краеведческого развития в регионе

В статье раскрыта историко-краеведческая деятельность библиотек Одесской области во второй половине 40-х -80 -х гг. ХХ в. Анализ этой деятельности свидетельствует о том, что несмотря на большие трудности (остаточный принцип финансирования культуры, и слабую материально-техническую базу библиотек) они стали настоящими центрами краеведческой работы в регионе. Библиотеки накопили за этот период значительную библиографическую базу по вопросам краеведения, приобрели большой опыт в работе с историкокраеведческими исследованиями. Практически в каждой библиотеке был собран краеведческий фонд, созданы каталоги и картотеки, включавшие многочисленные материалы по различной краеведческой тематике. Впрочем, краеведческая деятельность библиотек области требует дальнейшего углубленного изучения, ведь к тому времени они, выступая региональными информационными центрами, занимались поиском, хранением и предоставлением в общественное пользование краеведческой литературы. На развитие библиотечного краеведения в регионе негативно сказались тенденции общественной жизни, вытекающие из самого характера существующего тоталитарного режима.

Ключевые слова: историческое краеведение, библиотека, культура, краеведческая литература, библиография. 
Shcherbyna N. F. Libraries and their activities in the context of historical and local history development in the region

The article reveals the historical and local history activities of the libraries of the Odessa region in the second half of the 40s - 80s XX century. The analysis of this activity indicates that despite the great difficulties (the residual principle of financing culture, and the weak material and technical base of libraries), they have become real centers of local history work in the region. During this period, libraries have accumulated a significant bibliographic base on local history issues, acquired extensive experience in working with local history research. In the development of library local lore, an important role was played by bibliographers of local lore of Odessa scientific libraries. Thanks to their activities, a local history fund was collected in almost every library, catalogs and card indexes were created, which included numerous materials on various local history topics. That is why libraries performed the social functions of education and culture units and became centers of local history. However, the regional studies of the regional libraries require further in-depth study, because by that time they, acting as regional information centers, were engaged in the search, storage and provision of local history literature for public use. The development of library local lore in the region was negatively affected by those general tendencies of social life arising from the very nature of the then totalitarian regime.

Keywords: historical local history, library, culture, local history literature, bibliography.

Стаття надійшла до редакції 21.05.2021 p. Прийнято до друку 31.05.2021 p.

Рецензент - д. і. н., проф. Набока О. В. 